\title{
Election rivals promise French R\&D boost
}

Paris. When French voters go to the polls this weekend in the first round of France's presidential elections, most will be indifferent to research. But the seven-year term of office of the winner of the final round, to be held on 7 May, will have a major impact on the shape in which French science enters the next millennium.

Research has not figured prominently during the campaign. This is hardly surprising, given that few issues have received serious debate in a campaign dominated by fratricidal squabbling between former prime minister Jacques Chirac, and the present incumbent, Edouard Balladur, both candidates for the Gaullist RPR party.

Of the three leading candidates, only Lionel Jospin, the Socialist candidate, has spelled out his detailed policy on research. But all claim that they would make research a national priority. Both Balladur and Chirac have promised to increase spending on science from 2.4 per cent of gross national product (GNP) to match that of the United States and Japan, currently around 2.8 per cent; Jospin has set an even more ambitious goal of 3 per cent.

But many researchers are sceptical that the claims by Balladur and Chirac amount to more than campaign rhetoric. Indeed, many argue that the traditional differences in the research policies of the left and right are alive and well.

While the modernization of French science began with the Gaullist government of 1958, largely because of preoccupations with defence and the nuclear industry, the tone of the last decade has been set by the enthusiastic policies of the socialist government elected in 1981 under President François Mitterrand.
Mitterrand not only declared research a national priority, but ensured that funding subsequently grew from 1.87 per cent of GNP in 1981 to 2.4 per cent in 1990 . Hubert Curien, who was science minister for much of the decade, developed a coherent long-

Fillon was forced to abort his attempts to reform the university system, for example.

Similarly, a six-month 'national consultation' on research, expected to result in a government white paper setting out a new national strategy for research, has produced few changes.

Many researchers see Jospin as having the most legitimate credentials as a defender of research. His approach to university research and higher education while minister for national education in the previous socialist government is widely considered as having been energetic and progressive, if sometimes controversial.

term policy, increased recruitment, prodded research organizations to become more efficient, and encouraged industry to do more research through tax credits and subsidies.

In contrast, memories remain fresh in the scientific community of the harsh cuts on research imposed by the Chirac-led government which held power between 1986 and 1988 , and argued, as part of wide cuts in public spending, that industry should bear more of the burden of funding research.

Similarly, some claim that much of the progress made under the socialists has been undone under the Balladur government, which came to power in 1993 . While research has not suffered cuts as brutal as between 1986 and 1988, funding has stagnated and recruitment has slowed - despite the scheduled retirement of half of all French researchers by 2005 .

Many of the initiatives launched by Francois Fillon, the minister for higher education and research, have either failed to materialize or ended in climbdowns. In 1993,

\section{CNRS budget crisis 'larger than admitted'}

Paris. Concern is growing that a funding crisis at France's largest research agency, the Centre National de la Recherche Scientifique (CNRS) may be much more serious than the government has admitted, and that government ministers may be unable - or unwilling - to resolve the problem.

The concern has been heightened by doubts over a recent promise by Francois Fillon, the research minister, to reimburse a FF500 million (\$100 million) deficit which the agency has accumulated over the past few years because payments from the state have failed to keep up with promises made in the annual budget.

In a statement released last week, several CNRS researchers claimed that the terms of the letter from the government to
CNRS formalizing this promise did not explicitly commit it to reimbursement of the debt, but rather provided an advance on this year's payments to the agency. They want an explicit and binding commitment by the government that would remain valid whoever wins the upcoming presidential elections.

Moreover, an official audit of CNRS finances will be made public next month, and sources familiar with the investigation say that the CNRS deficit may not be FF500 million, but as much as FF2.5 billion. The budget for laboratory equipment and supplies is reported to make up FF1 billion of this debt, equivalent to an entire year's allocations. A further deficit of FF1.5 billion is said to have accumulated in the salary budget.
D. B.
What sets Jospin apart from the other candidates, say some

tre).

observers, is that he has a genuine enthusiasm for research. This is attributable in part to the company he keeps; his main adviser and close friend is Claude Allègre, head of the Institut du Physique du Globe at the University of Paris VI, and formerly Jospin's director of higher education.

In Jospin's current campaign, issues concerning research and higher education are being handled by another geophysicist, Vincent Courtillon, who heads the Laboratory of Palaeomagnetism and Geodynamics on the same campus as Allègre, and is chairman of the European Union of Geosciences.

Courtillon says that "independent evaluation" would be a key element of Jospin's research policies. In particular, he would set up committees made up of both French and foreign experts to evaluate all government policies, including space.

Jospin would also increase recruitment of young researchers to the Centre Nationale de la Recherche Scientifique (CNRS), France's largest research organization, and introduce a three-year plan to redress the agency's financial crisis (see below). But recruits would be discouraged from pursuing their entire career within CNRS.

In a bid to encourage greater mobility, one-third of such recruits would be encouraged to transfer to the universities after 15 or so years at CNRS, and another third to industry, according to Courtillon.

The election of Balladur would not mean a "revolution" in research, according to Thierry de Mazencourt, his campaign adviser on industrial, commercial and research issues. "The system is not catastrophic", he says. What it needs are many low-profile improvements.

Balladur's main priority, says de Mazencourt, would be to improve links between industrial and fundamental research. In particular, he would create a series of "regional networks for technological diffusion".

Declan Butler 